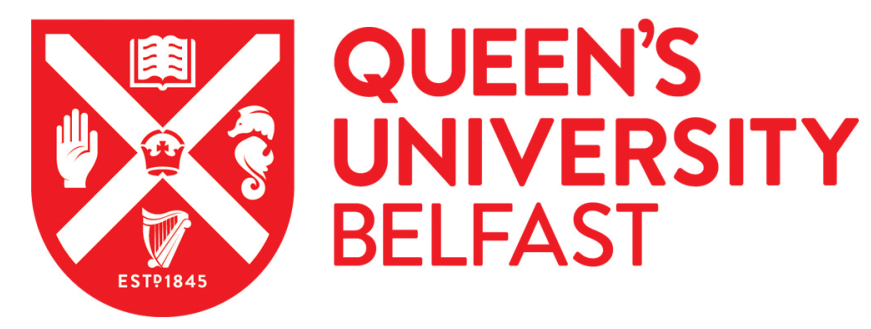

\title{
The common vaginal commensal bacterium Ureaplasma parvum is associated with chorioamnionitis in extreme preterm labour
}

Cox, C., Saxena, N., Watt, A. P., Gannon, C., McKenna, J. P., Fairley, D. J., Sweet, D., Shields, M. D., Cosby, S. L., \& Coyle, P. V. (2016). The common vaginal commensal bacterium Ureaplasma parvum is associated with chorioamnionitis in extreme preterm labour. The Journal of Maternal-Fetal \& Neonatal Medicine.

https://doi.org/10.3109/14767058.2016.1140734

Published in:

The Journal of Maternal-Fetal \& Neonatal Medicine

Document Version:

Peer reviewed version

Queen's University Belfast - Research Portal:

Link to publication record in Queen's University Belfast Research Portal

Publisher rights

(C) 2016 Taylor \& Francis

This is an Accepted Manuscript of an article published by Taylor \& Francis in

The Journal of Maternal-Fetal \& Neonatal Medicine on 22/1/2016, available online:

http://wwww.tandfonline.com/10.3109/14767058.2016.1140734

\section{General rights}

Copyright for the publications made accessible via the Queen's University Belfast Research Portal is retained by the author(s) and / or other copyright owners and it is a condition of accessing these publications that users recognise and abide by the legal requirements associated with these rights.

Take down policy

The Research Portal is Queen's institutional repository that provides access to Queen's research output. Every effort has been made to ensure that content in the Research Portal does not infringe any person's rights, or applicable UK laws. If you discover content in the Research Portal that you believe breaches copyright or violates any law, please contact openaccess@qub.ac.uk. 
Taylor \& Francis

Taylor \& Francis Group

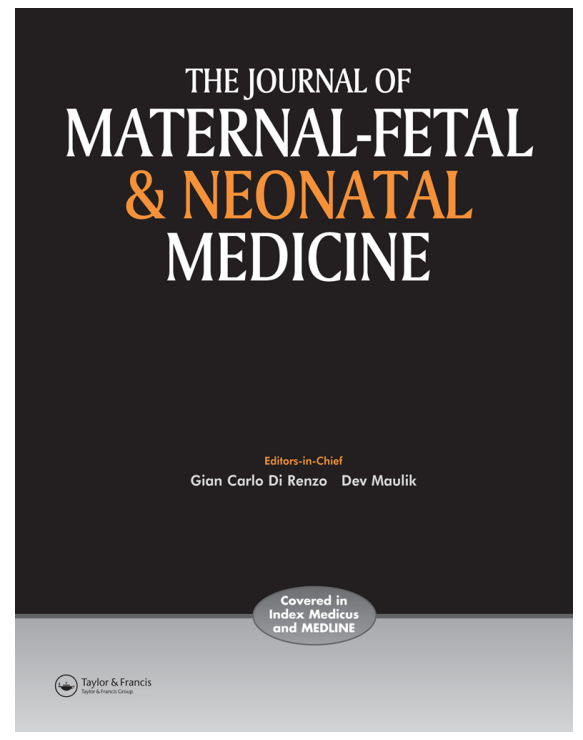

\title{
The common vaginal commensal bacterium Ureaplasma parvum is associated with chorioamnionitis in extreme preterm labour
}

\author{
Ciara Cox, Nita Saxena, Alison P Watt, Caroline Gannon, James P McKenna, Derek \\ J Fairley, David Sweet, Michael D Shields, Sara L Cosby, Peter V Coyle
}

Doi: $10.3109 / 14767058.2016 .1140734$

\begin{abstract}
Objective: To assess the association of vaginal commensal and low grade pathogenic bacteria including Ureaplasma parvum, Ureaplasma urealyticum, Mycoplasma hominis, Mycoplasma genitalium, Group B Streptococcus (GBS), and Gardnerella vaginalis, in women who delivered preterm at less than 37 weeks gestation in the presence or absence of inflammation of the chorioamnionitic membranes.
\end{abstract}

Methods: A case control study involving women who delivered before 37 weeks gestation with and without inflammation of chorioamnionitic membranes.

A total of 57 placental samples were histologically examined for polymorphonuclear leukocyte infiltration of placental tissue for evidence of chorioamnionitis, and by type-specific nucleic acid amplification for evidence of infection with one or more of the target bacteria. Demographic data was collected for each mother.

Results: Amongst the 57 placental samples, $42.1 \%$ had chorioamnionitis and $24.6 \%$ delivered in the second trimester of pregnancy; U. parvum, U. urealyticum, G. vaginalis and GBS were all detected in the study with respective prevalence of $19.3 \%, 3.5 \%, 17.5 \%$ and $15.8 \% ;$ M.genitalium and M. hominis were not detected. U. parvum was significantly associated with chorioamnionitis ( $p$ value $=0.02$; OR 5.0; $(95 \% \mathrm{Cl} 1.2-21.5)$ and was more common in women who delivered in the second $(35.7 \%)$ compared to the third trimester of pregnancy $(13.9 \%)$. None of the other bacteria were associated with chorioamnionitis or earlier delivery and all $G$. vaginalis positive women delivered in the third trimester of pregnancy ( $p$ value 0.04).

Conclusions: The detection of U. parvum in placental tissue was significantly associated with acute chorioamnionitis in women presenting in extreme preterm labour.

(c) 2016 Taylor \& Francis. This provisional PDF corresponds to the article as it appeared upon acceptance. Fully formatted PDF and full text (HTML) versions will be made available soon.

DISCLAIMER: The ideas and opinions expressed in the journal's Just Accepted articles do not necessarily reflect those of Taylor \& Francis (the Publisher), the Editors or the journal. The Publisher does not assume any responsibility for any injury and/or damage to persons or property arising from or related to any use of the material contained in these articles. The reader is advised to check the appropriate medical literature and the product information currently provided by the manufacturer of each drug to be administered to verify the dosages, the method and duration of administration, and contraindications. It is the responsibility of the treating physician or other health care professional, relying on his or her independent experience and knowledge of the patient, to determine drug dosages and the best treatment for the patient. Just Accepted articles have undergone full scientific review but none of the additional editorial preparation, such as copyediting, typesetting, and proofreading, as have articles published in the traditional manner. There may, therefore, be errors in Just Accepted articles that will be corrected in the final print and final online version of the article. Any use of the Just Accepted articles is subject to the express understanding that the papers have not yet gone through the full quality control process prior to publication. 
The common vaginal commensal bacterium Ureaplasma parvum is associated with chorioamnionitis in extreme preterm labour

\section{Co-authors}

Ciara Cox ${ }^{1,2}$ (ciara.cox@belfasttrust.hscni.net); Nita Saxena ${ }^{3}$

(nita.saxena@setrust.hscni.net); Alison P Watt ${ }^{1}$ (alison.watt@belfasttrust.hscni.net);

Caroline Gannon ${ }^{4}$ (caroline.gannon@belfasttrust.hscni.net); James P McKenna ${ }^{1}$

(james.mckenna@belfasttrust.hscni.net); Derek J Fairley ${ }^{1,2}$

(derek.fairley@belfasttrust.hscni.net); David Sweet ${ }^{3}$ (david.sweet@belfasttrust.hscni.net);

Michael D Shields ${ }^{2,3}$ (m.shields@qub.ac.uk); Sara LCosby² (I.cosby@qub.ac.uk); Peter V

Coyle $^{1}$ (peter.coyle@belfasttrust.hscni.net)

${ }^{1}$ Department of Microbiology, Belfast Health and Social Care Trust, Belfast, Northern Ireland, United Kingdom

${ }^{2}$ Centre for Infection and Immunity, Queen's University Belfast, Northern Ireland, United Kingdom

${ }^{3}$ Royal Belfast Hospital for Sick Children, Royal Hospitals Group, Belfast, United Kingdom ${ }^{4}$ Department of Histopathology, Belfast Health and Social Care Trust, Belfast, Northern Ireland, United Kingdom

\section{Corresponding author}

Ciara Cox

Regional Virology - Kelvin Buildings

Royal Victoria Hospital

Grosvenor Road

Belfast BT12 6BA

Tel 02890638295

ciara.cox@belfasttrust.hscni.net

Running title: Ureaplasma parvum and preterm labour 


\section{Objective}

To assess the association of vaginal commensal and low grade pathogenic bacteria including Ureaplasma parvum, Ureaplasma urealyticum, Mycoplasma hominis, Mycoplasma genitalium, Group B Streptococcus (GBS), and Gardnerella vaginalis, in women who delivered preterm at less than 37 weeks gestation in the presence or absence of inflammation of the chorioamnionitic membranes.

\section{Methods}

A case control study involving women who delivered before 37 weeks gestation with and without inflammation of chorioamnionitic membranes.

A total of 57 placental samples were histologically examined for polymorphonuclear leukocyte infiltration of placental tissue for evidence of chorioamnionitis, and by type-specific nucleic acid amplification for evidence of infection with one or more of the target bacteria. Demographic data was collected for each mother.

\section{Results}

Amongst the 57 placental samples, $42.1 \%$ had chorioamnionitis and $24.6 \%$ delivered in the second trimester of pregnancy; U. parvum, U. urealyticum, G. vaginalis and GBS were all detected in the study with respective prevalence of $19.3 \%, 3.5 \%, 17.5 \%$ and $15.8 \%$; M.genitalium and M. hominis were not detected. U. parvum was significantly associated with chorioamnionitis ( $p$ value $=0.02$; OR 5.0 ; $(95 \% \mathrm{Cl} 1.2-21.5)$ and was more common in women who delivered in the second $(35.7 \%)$ compared to the third trimester of pregnancy (13.9\%). None of the other bacteria were associated with chorioamnionitis or earlier delivery and all G.vaginalis positive women delivered in the third trimester of pregnancy ( $p$ value 0.04). .

\section{Conclusions}

The detection of $U$. parvum in placental tissue was significantly associated with acute chorioamnionitis in women presenting in extreme preterm labour.

\section{Keywords}

Pregnancy, placenta, trimester, intra-amniotic, Ureaplasma, prematurity, PCR, bacteria 


\section{Introduction}

Preterm delivery is increasing and affects one baby in every 13 born (World Health Organisation, 2013). Preterm delivery, where a baby is born alive before completion of 37 gestational weeks, accounts for $75 \%$ of perinatal mortalities and a significant number of long term neonatal morbidities including chronic lung disease [1,2]. Intra-amniotic infection is currently a common cause of preterm delivery and is frequently caused by ascending genital tract infection [3,4]. Following ascent, microbes are capable of eliciting an inflammatory response in the chorioamniotic membrane by initiating an innate immune response resulting in the release of pro-inflammatory cytokines which are thought to trigger early labour $[5,6]$. Inflammation occurring across the chorioamniotic membrane is termed chorioamnionitis and has long been associated with preterm delivery [5,7-9].

Alteration of the vaginal microbiota and $\mathrm{pH}$ facilitates the ascent of microbes to the normally sterile amniotic cavity. The altered $\mathrm{pH}$ reflects a reduction in the protective lactobacilli species and an overgrowth of anaerobic commensals, including Mycoplasma and Ureaplasma species, a mechanism thought to facilitate ascending infection and adverse sequelae [4]. Ureaplasma and Mycoplasma are Gram negative facultative anaerobic bacteria which frequently colonise the genitourinary tract [10]. While Ureaplasma urealyticum, Ureaplasma parvum and Mycoplasma hominis can be regarded as commensal bacteria of the vaginal micro flora, there is supporting evidence they may act as low grade pathogens in pregnancy [11]. Mycoplasma genitalium is recognised as a low-grade urogenital pathogen that has been associated with cervicitis and complications during pregnancy [12-15]. Gardnerella vaginalis is a common vaginal commensal that is significantly altered in bacterial vaginosis, a microbial disturbance that is known to be linked to preterm labour [16]. Streptococcus agalactiae more commonly known as Group B Streptococcus [GBS], occurs as an intermittent vaginal coloniser present in up to $30 \%$ of pregnant women [17]. GBS is associated with early onset neonatal sepsis which has a significantly higher prevalence in preterm pregnancies $[17,18]$.

The present study aimed to assess if the detection of any of the 4 genital Mollicutes, $G$. vaginalis and/or GBS in placental tissue was associated with the presence of chorionic plate and/or membrane inflammation (chorioamnionitis) in a cohort of women who delivered less than 37 weeks gestation and if their presence was linked with earlier preterm delivery. 


\section{Methods}

\section{Inclusion and Exclusion Criteria}

Placental specimens from women presenting in labour at the Royal Jubilee Maternity Hospital at $<37$ weeks gestation were eligible for enrollment and term pregnancies were excluded. In any pregnancy where a shared placenta was present, i.e in monochorionic twins or dichorionic triplets only one placental sample was included. Where twins or triplets did not share a placenta, independent samples for each baby were taken for analysis.

\section{Demographic Data}

Forty-nine pregnant women were enrolled into the study. There were 48 white European women and 1 Asian woman recruited. The median age of enrolled women was 29 years (range 18-42 years) with a median gestational age of 29 completed weeks (range 27-31 weeks). There were: $39 / 49$ (79.6\%) single pregnancies; $6 / 49(12.2 \%)$ twin pregnancies and $4 / 49(8.2 \%)$ triplet pregnancies. Six babies (sample numbers 2, 11, 37, 54, 55 and 64) were excluded from analysis due to sharing a placenta, leaving a total of 57 independent placental samples included in the study. A total of 33 of the 57 (57.9\%) were delivered by Caesarean section, with a median birth weight of $1168 \mathrm{~g}$ (range $890.75 \mathrm{~g}-1598.75 \mathrm{~g}$ ).

\section{Specimen Collection}

Placental tissue samples were collected and sampled for later molecular analysis before being sent for histology to the Paediatric Pathology department of the Belfast HSC Trust. Deep placental tissue as opposed to superficial sampling at the mucosal surface was collected to decrease the risk of accidental bacterial contamination. Tissue samples were collected from the sub-chorionic plate area on the fetal side of the placenta. After lifting off the amnion membrane layer, a section of underlying tissue $1 \mathrm{~cm}^{3}$ was dissected out aseptically and stored in sterile $25 \mathrm{ml}$ universal tubes at $-70^{\circ} \mathrm{C}$ prior to nucleic acid extraction.

\section{Histopathology}

Each placental sample was subjected to a standard histopathological examination by a Consultant Paediatric Pathologist and categorised for the presence or absence of chorioamnionitis. The Pathologist was blinded to clinical outcomes and acute chorioamnionitis was defined if there were stereotypical patterns of inflammatory changes in chorionic plate or membranes (19). 


\section{Molecular testing}

Nucleic acid extraction

Nucleic acid extracts were prepared using tissue protocol reagents from Qiagen QIAamp kits (Crawley, UK). Individual 20mg tissue samples were cut from stored specimens using sterile scalpel blades. They were homogenised in Buffer ATL $(180 \mu l)$ by bead-beating for 30 seconds in a $2 \mathrm{ml}$ micro-centrifuge tube using sterile $3 \mathrm{~mm}$ tungsten carbide beads. A $20 \mu \mathrm{l}$ volume of Proteinase $\mathrm{K}$ was added and the homogenised samples were incubated at $56^{\circ} \mathrm{C}$ for 3 hours to completely dissolve the tissue. The resulting lysates were extracted using a standard QIAamp spin column protocol. Total nucleic acid from each specimen was eluted in

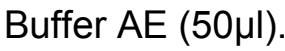

\section{Real-time quantitative PCR}

Nucleic acid extracts were subjected to 6 real time TaqMan ${ }^{\circledR}$ qPCRs for the separate detection of: $U$. urealyticum and $U$. parvum urease genes (20); M. hominis 16s rRNA gene (21); M. genitalium MgpB gene (22); GBS sip gene (23); G. vaginalis 16s rRNA (24). Validation confirming the performance characteristics of each qPCR assay was undertaken separately before their application to the samples collected. Logarithmic serial dilutions of gene-specific plasmid standards with a known DNA concentration measured with a Nanodrop 2000 Spectrophotometer (Thermoscientific, Epsom, UK), were used to demonstrate a limit of detection between $10^{0}-10^{1}$ gene copies per reaction for each assay. No cross reactivity was observed for any of the GPCR assays when tested against a panel of nucleic acid extracts of 40 different species.

All assays were carried out using $1 X$ Platinum $^{\circledR}$ Quantitative PCR SuperMix-UDG (Life Technologies, Paisley, UK). Final working concentrations of reagents in the qPCR singular assays were as follows: $0.4 \mu \mathrm{M}$ forward and reverse primer, $0.1 \mu \mathrm{M}$ TaqMan ${ }^{\circledR}$ probe, $0.2 \mu \mathrm{g}$ $\mathrm{ml}^{-1}$ BSA (Thermoscientific, Epsom, UK) and $4 \mathrm{mM} \mathrm{MgCl}_{2}$ (Life Technologies, Paisley, UK). Final reaction volumes of $10 \mu \mathrm{l}$ made up of $2 \mu \mathrm{l}$ nucleic acid extract and $8 \mu \mathrm{l}$ mastermix were used. All real-time PCR reactions were performed using a LightCycler ${ }^{\circledR} 480$ thermal cycler (Roche Diagnostics, Mannheim, Germany) with the following cycling conditions: $95^{\circ} \mathrm{C}$ for 5 min, followed by 45 cycles of $95^{\circ} \mathrm{C}$ for 15 seconds and $59^{\circ} \mathrm{C}$ for 45 seconds. MS2 internal control was included in each real-time PCR run to monitor for inhibition, positive and negative controls specific to each qPCR assay were included in each run to monitor performance. Results were analysed using LightCycler ${ }^{\circledR} 480$ software, version 1.5 (Roche Diagnostics, Mannheim, Germany) and recorded as cycle threshold $\left(\mathrm{C}_{\mathrm{T}}\right)$ values; reactions which failed to produce a $\mathrm{C}_{\mathrm{T}}$ value after 45 cycles were recorded as negative. 


\section{Statistical Analysis}

Statistical analyses were performed using IBM SPSS 19.0 (SPSS Science, Chicago, IL, USA) to combine clinical and molecular data; $p$ values of $<0.05$ (2 tailed) were regarded as significant. Placental tissue samples from women in the study were dichotomously categorised as (a) with or without chorioamnionitis (b) delivery in second (13-26 weeks gestation) or third (> 26 weeks gestation) trimesters of pregnancy. Fisher's Exact Test was used to compare the prevalence of the 6 organisms between the groups.

\section{Results}

\section{Clinical characteristics}

Amongst the 57 placentas, 24 (42.1\%) and 33 (57.9\%) respectively had or did not have histologically confirmed chorioamnionitis. A total of 14 (24.6\%) and 43 (75.4\%) women delivered respectively in the second and third trimester of pregnancy. Details from histopathology reports for each patient are outlined in table S1.

\section{Molecular Data}

Of the 57 placental samples tested, 26 (45.6\%) were positive for at least one of the 6 target organisms. U. parvum was detected in 11 (19.3\%) samples; G. vaginalis in $10(17.5 \%)$ samples; GBS in 9 (15.8\%) samples and U. Urealyticum in 2 (3.5\%) samples. M. hominis and $M$. genitalium were not detected in any samples. Placental samples positive for each bacterial target are outlined in table $\mathrm{S} 2$.

\section{Molecular and Clinical Comparisons}

The prevalence of $U$. parvum and marginally $U$. urealyticum and GBS were higher in samples with evidence of inflammation however only $U$. parvum reached statistical significance $(p=0.02)$. Where chorioamnionitis was present or absent $U$. parvum was detected in $8(33.3 \%)$ and $3(9.1 \%)$ samples, GBS was detected in $4(16.6 \%)$ and $5(15.2 \%)$ samples and $U$. urealyticum was detected in 1 sample from each group $(4.2 \%$ and $3 \%$ respectively). G. vaginalis was more commonly detected in samples without evidence of inflammation but this was not statistically significant $(p=0.12)$ Where chorioamnionitis was present or absent, G. vaginalis was respectively detected in $2(8.3 \%)$ and $8(24.2 \%)$ samples. The comparison of organism prevalence between women with and without confirmed chorioamnionitis are summarised in Table 1.

The prevalence of organisms respectively detected in the second $(n=14)$ and third $(n=43)$ trimester of pregnancy were for U. parvum - 5 (35.7\%) and $6(14 \%)$; for U. urealyticum - 1 $(7.1 \%)$ and $1(2.3 \%)$ and for GBS $-3(21.4 \%)$ and $6(14 \%)$. All 10 G. vaginalis positive 
samples were detected in the third trimester of pregnancy (23.3\%). The comparisons between both trimesters of pregnancy are outlined in Table 2 . The higher prevalence of $U$. parvum in women delivering in $2^{\text {nd }}$ trimester compared to $3^{\text {rd }}$ trimester approached statistical significance $(p=0.07)$. The opposite association was seen for $G$. vaginalis where a higher prevalence in women delivering in the third trimester compared to the second trimester reached statistical significance $(p=0.04)$. While GBS and $U$. urealyticum had higher prevalences in women delivering in the second trimester these did not approach statistical significance ( $p=0.50$ and $p=0.40$ respectively).

\section{Discussion}

While intrauterine infection is regarded as an important cause of preterm delivery $[3,4]$ the mechanism involved is less clear. The vaginal microbiota is thought to be protective against preterm labour and its disruption, as in bacterial vaginosis, is felt to be a risk factor allowing low pathogenic vaginal bacteria to ascend the genitourinary tract[3,4]. The focus of this study was to determine if common vaginal bacteria such as Ureaplasma and Mycoplasma species, GBS and $G$. vaginalis were associated with inflammatory changes in the placenta of women delivering at $<37$ weeks gestation. Highly sensitive qPCR assays, including ones that could discriminate between $U$. urealyticum and $U$. parvum, were chosen to overcome technical deficiencies of previous studies that have produced conflicting findings [25-30]. In the current study 57 placental tissue samples from 49 women were tested. G. vaginalis, GBS, $U$. urealyticum and $U$. parvum were detected while $M$. genitalium and $M$. hominis were not detected. $U$. parvum had the highest prevalence (19.3\%), followed respectively by $G$. vaginalis (17.5\%), GBS (15.8\%) and U. urealyticum (3.5\%).

Infiltration of the chorioamnion by polymorphonuclear leukocytes on histopathological examination was used as a biomarker of inflammation and was confirmed in 24 (42.1\%) placentas in the study, suggesting that just over $40 \%$ of the preterm births were potentially linked to infection. While detection of $U$. urealyticum and GBS were more common in placental tissue with inflammation compared to tissue without, the proportions did not reach statistical significance. However, the detection rate of $U$. parvum in tissue with chorioamnionitis was significantly higher $(p=0.02)$ than the rate detected in tissue without chorioamnionitis suggesting it could have an association with inflammation leading to preterm labour. A larger study should address this association and whether the association was linked to treatable dysbiotic disruption of the vaginal microbiota.

Traditionally $U$. urealyticum biovars 1 and 2 were regarded as a single species but recently they have been separated into two distinct species, namely $U$. urealyticum (formerly biovar 2) and U. parvum (formerly biovar 1). This has confounded results in publications prior to the separation [31]. Although previous studies associated $U$. urealyticum with stillbirth, 
spontaneous abortion, chorioamnionitis and preterm labour [32], the majority failed to discriminate between both species and used insensitive detection methods [25-28]. Therefore clarity is lacking on the respective roles of $U$. urealyticum and $U$. parvum in pregnancy[33]. Although genital Mycoplasma, Ureaplasma and other pathogens have been associated with preterm delivery [34, 35], a high proportion of preterm births have no identifiable cause confirmed [36]. At present, the knowledge base regarding intrauterine infection is inconclusive, in particular the ability of Mycoplasma and Ureaplasma species to induce inflammatory responses in the uterine cavity [27]. Assessing the association of Ureaplasma species with chorioamnionitis in women delivering preterm is important to help assess their role as pathogens in intrauterine infection and preterm delivery [32,37]. The separate detection of $U$. urealyticum and $U$. parvum in clinical specimens from women with and without chorioamnionitis is a prerequisite for this type of study.

Previous studies have reported that inflammatory response induced by U.parvum is frequently associated with preterm delivery $[38,39]$. While $G$. vaginalis and $U$. parvum have similar colonisation prevalence rates of $>50 \%$ in the vaginal microbiota of pregnant and nonpregnant women $[40,41]$, their recovery in the current study in relation to chorioamnionitis and the gestational age at delivery were inverse. U. parvum showed a strong association with placenta inflammatory infiltration and with delivery in second trimester supporting an association with preterm labour. G. vaginalis showed no association with placenta inflammatory infiltration and was more prevalent at later gestational ages suggesting a nonpathogenic role in preterm labour.

Findings from this study coincide with those reporting a strong association between intrauterine infection and delivery at $<30$ weeks gestation [36]. Furthermore, a recent study reported a lower preterm delivery rate in pregnant women treated for $M$. hominis and Ureaplasma species [42]. Those findings and the results of the current study support the need for further research into the pathogenesis of $U$. parvum associated preterm labour and the potential for its prevention. Interestingly GBS showed no association with inflammatory infiltration of the placenta, and so did not appear to be linked to preterm labour through urogenital inflammation. However like $U$. parvum it was more common with earlier gestational delivery, suggesting GBS might have a non-inflammatory role in preterm labour. One possible explanation for this might be linked to the recent observation in gravid primates that in-utero infection with GBS can result in the down regulation of multiple cytokeratins and other cytoskeletal genes critical for maintenance of cellular membrane integrity and tensile strength, potentially leading to preterm labour [43]. These changes took place in the absence of inflammation. Additionally GBS has been shown to down-modulate the innate response to 
infection in the chorioamnion which could again explain the apparent lack of inflammation in the placenta samples tested [44].

Although relatively small in overall numbers, we believe a real strength of the study was the recruitment of a number of women with extreme preterm pregnancies. From a technical perspective culture-based detection methods often used in the diagnosis of intrauterine infection in women with adverse pregnancy outcomes lack precision and are suboptimal in the identification of the highly fastidious species of the Ureaplasma and Mycoplasma genera. Thus another main strength of this study was the utilisation of qPCR assays with high analytical sensitivity and specificity to target bacteria that have been previously associated with pregnancy complications and with some that are also common in the vaginal microbiota. The application of these assays to placental tissue with and without histological evidence of chorioamnionitis, allowed a link to be established with a potential trigger of preterm labour. A perceived weakness in the study design could be exclusion of term pregnancies however since the question addressed was the association with inflammation in preterm delivery and not whether the infections triggered it, the rational controls had to be preterm deliveries lacking histological inflammation of the chorioamniotic membranes. The link seen with $U$. parvum and earlier preterm delivery suggests the association would be absent at term and it is probably causal.

The results suggest an association between $U$. parvum and inflammation of the chorioamniotic membrane in preterm labour; the increased number of positive women with delivery in the second trimester would also suggest an association with preterm delivery. The mechanism for $U$. parvum gaining access to the chorioamnion was not addressed. While a potential association for GBS in preterm delivery was also suggested by the findings, the data did not support a role in placental inflammation. The findings suggest the need for further investigation of the role of $U$. parvum as a trigger of preterm labour and the findings would support an extension of the present study to include term pregnancies.

Acknowledgements: We are indebted to the permission of the mothers involved and their consent to take part.

None

Disclosure of Interests: None

Details of ethics approval: All specimens were collected with informed consent under ethics approval from Office for Research Ethics Committees Northern Ireland (ORECNI) REC reference number: 07/NIR02/144. Date of approval $22^{\text {nd }}$ February 2008. 


\section{References}

(1) Mathews TJ, MacDorman MF. Infant mortality statistics from the 2006 period linked birth/infant death data set. National Vital Statistics Reports 2010 Apr 30;58(17):1-31.

(2) Waites KB, Katz B, Schelonka RL. Mycoplasmas and ureaplasmas as neonatal pathogens. Clin Microbiol Rev 2005 Oct 2005;18(4):757-789

(3) Witkin SS The vaginal microbiome, vaginal anti-microbial defence mechanisms and the clinical challenge of reducing infection-related preterm birth. BJOG. 2015:122(2):213-8.

(4) Pararas MV, Skevaki CL, Kafetzis DA. Preterm birth due to maternal infection: Causative pathogens and modes of prevention. European Journal of Clinical Microbiology \& Infectious Diseases 2006 Sep;25(9):562-569.

(5) Romero R, Espinoza J, Kusanovic JP, Gotsch F, Hassan S, Erez O, et al. The preterm parturition syndrome. BJOG 2006 Dec;113 Suppl 3:17-42.

(6) Gomez R, Romero R, Nien JK, Medina L, Carstens M, Kim YM, et al. Idiopathic vaginal bleeding during pregnancy as the only clinical manifestation of intrauterine infection. $J$ Matern Fetal Neonatal Med 2005 Jul;18(1):31-37.

(7) Miralles R, Hodge R, McParland PC, Field DJ, Bell SC, Taylor DJ, et al. Relationship between antenatal inflammation and antenatal infection identified by detection of microbial genes by polymerase chain reaction. Pediatr Res 2005 Apr;57(4):570-577.

(8) Holcroft CJ, Askin FB, Patra A, Allen MC, Blakemore KJ, Graham EM. Are histopathologic chorioamnionitis and funisitis associated with metabolic acidosis in the preterm fetus? Am J Obstet Gynecol 2004 Dec;191(6):2010-2015.

(9) Goldenberg RL, Andrews WW, Mercer BM, Moawad AH, Meis PJ, lams JD, et al. The preterm prediction study: granulocyte colony-stimulating factor and spontaneous preterm birth. National Institute of Child Health and Human Development Maternal-Fetal Medicine Units Network. Am J Obstet Gynecol 2000 Mar;182(3):625-630.

(10) Redelinghuys MJ, Ehlers MM, Dreyer AW, Lombaard HA, Kock MM. Comparison of the new Mycofast Revolution assay with a molecular assay for the detection of genital mycoplasmas from clinical specimens. BMC Infect Dis 2013 Sep 30;13:453-458

(11) Kwak DW, Hwang HS, Kwon JY, Park YW, Kim YH. Co-infection with vaginal Ureaplasma urealyticum and Mycoplasma hominis increases adverse pregnancy outcomes in patients with preterm labor or preterm premature rupture of membranes. J Matern Fetal Neonatal Med 2014 Mar;27(4):333-337.

(12) Short VL, Jensen JS, Nelson DB, Murray PJ, Ness RB, Haggerty CL. Mycoplasma genitalium among young, urban pregnant women. Infect Dis Obstet Gynecol. 2010;2010:984760.

(13) Tosh AK, Van Der Pol B, Fortenberry JD, Williams JA, Katz BP, Batteiger BE, et al. Mycoplasma genitalium among adolescent women and their partners. Journal of Adolescent Health 2007 May;40(5):412-417. 
(14) Averbach SH, Hacker MR, Yiu T, Modest AM, Dimitrakoff J, Ricciotti HA. Mycoplasma genitalium and preterm delivery at an urban community health center. Int J Gynaecol Obstet. 2013 Oct;123(1):54-7.

(15) Edwards RK, Ferguson RJ, Reyes L, Brown M, Theriaque DW, Duff P. Assessing the relationship between preterm delivery and various microorganisms recovered from the lower genital tract. J Matern Fetal Neonatal Med. 2006 Jun;19(6):357-63.

(16) Africa CW, Nel J, Stemmet M. Anaerobes and bacterial vaginosis in pregnancy: virulence factors contributing to vaginal colonisation. Int J Environ Res Public Health 2014 Jul 10;11(7):6979-7000.

(17) Verani JR, McGee L, Schrag SJ, Division of Bacterial Diseases, National Center for Immunization and Respiratory Diseases, Centers for Disease Control and Prevention (CDC). Prevention of perinatal group B streptococcal disease--revised guidelines from CDC, 2010. MMWR Recomm Rep 2010 Nov 19;59(RR-10):1-36.

(18) Verani JR, Schrag SJ. Group B streptococcal disease in infants: progress in prevention and continued challenges. Clin Perinatol 2010 Jun;37(2):375-392.

(19) Kraus FT, Redline RW, Gersell DJ, Nelson DM, Dicke JM (2004) Placental Pathology; Atlas of Nontumor Pathology. Pub: American Registry of Pathology / Armed Forces Institute of Pathology

(20) Vancutsem E, Soetens O, Breugelmans M, Foulon W, Naessens A. Modified real-time PCR for detecting, differentiating, and quantifying Ureaplasma urealyticum and Ureaplasma parvum. J Mol Diagn 2011 Mar;13(2):206-212.

(21) Pascual A, Jaton K, Ninet B, Bille J, Greub G. New Diagnostic Real-Time PCR for Specific Detection of Mycoplasma hominis DNA. Int $J$ Microbiol 2010;2010:10.1155/2010/317512. Epub 2010 Jul 25.

(22) Chalker VJ, Jordan K, Ali T, Ison C. Real-time PCR detection of the mg219 gene of unknown function of Mycoplasma genitalium in men with and without non-gonococcal urethritis and their female partners in England. J Med Microbiol 2009 Jul;58(Pt 7):895-899.

(23) Bergh K, Stoelhaug A, Loeseth K, Bevanger L. Detection of group B streptococci (GBS) in vaginal swabs using real-time PCR with TaqMan probe hybridization. Indian J Med Res 2004 May;119 Suppl:221-223.

(24) Cox C, McKenna JP, Watt AP, Coyle PV, New assay for Gardnerella vaginalis loads correlates with Nugent scores and has potential in the diagnosis of bacterial vaginosis. Journal of Medical Microbiology 2015 64, 978-984

(25) Kirchner L, Helmer H, Heinze G, Wald M, Brunbauer M, Weninger M, et al. Amnionitis with Ureaplasma urealyticum or other microbes leads to increased morbidity and prolonged hospitalization in very low birth weight infants. European Journal of Obstetrics, Gynecology, \& Reproductive Biology 2007 Sep;134(1):44-50.

(26) Oh KJ, Lee KA, Sohn YK, Park CW, Hong JS, Romero R, et al. Intraamniotic infection with genital mycoplasmas exhibits a more intense inflammatory response than intraamniotic infection with other microorganisms in patients with preterm premature rupture of membranes. Am J Obstet Gynecol 2010 Sep;203(3):211.e1-211.e8. 
(27) Egawa T, Morioka I, Morisawa T, Yokoyama N, Nakao H, Ohashi M, et al. Ureaplasma urealyticum and Mycoplasma hominis presence in umbilical cord is associated with pathogenesis of funisitis. Kobe J Med Sci 2007;53(5):241-249.

(28) Namba F, Hasegawa T, Nakayama M, Hamanaka T, Yamashita T, Nakahira K, et al. Placental features of chorioamnionitis colonized with Ureaplasma species in preterm delivery. Pediatr Res 2010 Feb;67(2):166-172.

(29) Gerber S, Vial Y, Hohlfeld P, Witkin SS. Detection of Ureaplasma urealyticum in second-trimester amniotic fluid by polymerase chain reaction correlates with subsequent preterm labor and delivery. J Infect Dis 2003 Feb 1;187(3):518-521.

(30) Choi SJ, Park SD, Jang IH, Uh Y, Lee A. The prevalence of vaginal microorganisms in pregnant women with preterm labor and preterm birth. Ann Lab Med 2012 May;32(3):194200.

(31) Robertson JA, Stemke GW, Davis JW,Jr, Harasawa R, Thirkell D, Kong F, et al. Proposal of Ureaplasma parvum sp. nov. and emended description of Ureaplasma urealyticum (Shepard et al. 1974) Robertson et al. 2001. Int J Syst Evol Microbiol 2002 Mar;52(Pt 2):587-597.

(32) Waites KB, Schelonka RL, Xiao L, Grigsby PL, Novy MJ. Congenital and opportunistic infections: Ureaplasma species and Mycoplasma hominis. Semin Fetal Neonatal Med 2009 Aug;14(4):190-199.

(33) Kacerovsky M, Pliskova L, Bolehovska R, Musilova I, Hornychova H, Tambor V, et al. The microbial load with genital mycoplasmas correlates with the degree of histologic chorioamnionitis in preterm PROM. Obstet Gynecol 2011 September 2011;205(3):213.e1213.e7.

(34) Romero R, Espinoza J, Goncalves LF, Kusanovic JP, Friel L, Hassan S. The role of inflammation and infection in preterm birth. Semin Reprod Med 2007 Jan;25(1):21-39.

(35) Goldman AS, Schmalstieg FC. The pathogenesis of chorioamnionitis. J Pediatr 2008 Jul;153(1):3-4.

(36) Goldenberg RL, Culhane JF. Prepregnancy health status and the risk of preterm delivery. Arch Pediatr Adolesc Med 2005 Jan;159(1):89-90.

(37) DiGiulio DB. Diversity of microbes in amniotic fluid. Semin Fetal Neonatal Med 2012 Feb;17(1):2-11.

(38) Kasper DC, Mechtler TP, Reischer GH, Witt A, Langgartner M, Pollak A, et al. The bacterial load of Ureaplasma parvum in amniotic fluid is correlated with an increased intrauterine inflammatory response. Diagnostic Microbiology \& Infectious Disease 2010 Jun;67(2):117-121.

(39) Fichorova RN. Onderdonk AB. Yamamoto H. Delaney ML. DuBois AM. Allred E. Leviton A. Extremely Low Gestation Age Newborns (ELGAN) Study Investigators. Maternal microbespecific modulation of inflammatory response in extremely low-gestational-age newborns. mBio $2011 ; 2(1): e 00280-10$. 
(40) Bayraktar MR, Ozerol IH, Gucluer N, Celik O. Prevalence and antibiotic susceptibility of Mycoplasma hominis and Ureaplasma urealyticum in pregnant women. Int J Infect Dis 2010 Feb;14(2):e90-5.

(41) Balashov SV, Mordechai E, Adelson ME, Gygax SE. Identification, quantification and subtyping of Gardnerella vaginalis in noncultured clinical vaginal samples by quantitative PCR. J Med Microbiol 2014 Feb;63(Pt 2):162-175.

(42) Vouga M, Greub G, Prod'hom G, Durussel C, Roth-Kleiner M, Vasilevsky S, et al. Treatment of genital mycoplasma in colonized pregnant women in late pregnancy is associated with a lower rate of premature labour and neonatal complications. Clin Microbiol Infect 2014 Oct;20(10):1074-9

(43) Vanderhoeven JP, Bierle CJ, Kapur RP, McAdams RM, Beyer RP, Bammler TK, et al. Group B streptococcal infection of the choriodecidua induces dysfunction of the cytokeratin network in amniotic epithelium: a pathway to membrane weakening. PLoS Pathog 2014 Mar 6;10(3):e1003920.

(44) Chang YC, Olson J, Beasley FC, Tung C, Zhang J, Crocker PR, et al. Group B Streptococcus engages an inhibitory Siglec through sialic acid mimicry to blunt innate immune and inflammatory responses in vivo. PLoS Pathog 2014 Jan;10(1):e1003846.

http://www.who.int/mediacentre/factsheets/fs363/en/ 
Table 1 Comparison of organism prevalence between women with or without chorioamnionitis and/or funisitis

\begin{tabular}{|c|c|c|c|c|c|c|}
\hline & \multicolumn{2}{|c|}{ Chorioamnionitis } & \multirow[b]{2}{*}{$P$ value ${ }^{\#}$} & \multirow{2}{*}{$\begin{array}{l}\text { Odds } \\
\text { ratio }\end{array}$} & \multicolumn{2}{|c|}{$\begin{array}{l}95 \% \text { confidence } \\
\text { intervals }\end{array}$} \\
\hline & $\begin{array}{c}\text { Present } \\
n=24\end{array}$ & $\begin{array}{l}\text { Absent } \\
n=33\end{array}$ & & & lower & upper \\
\hline U.parvum & $33.3 \%(8)$ & $9.1 \%(3)$ & 0.02 & 5.0 & 1.2 & 21.5 \\
\hline U.urealyticum & $4.2 \%(1)$ & $3.0 \%(1)$ & 0.82 & 1.4 & 0.08 & 23.4 \\
\hline G.vaginalis & $8.3 \%(2)$ & $24.2 \%(8)$ & 0.12 & 0.3 & 0.05 & 1.4 \\
\hline GBS & $16.6 \%(4)$ & $15.2 \%(5)$ & 0.88 & 1.1 & 0.27 & 4.7 \\
\hline
\end{tabular}

"Fisher's Exact test.

Table 2 Comparison of organism prevalence between women delivering in second and third trimesters of pregnancy

\begin{tabular}{|c|c|c|c|c|c|c|}
\hline & \multicolumn{2}{|c|}{ qPCR positives } & \multirow[b]{2}{*}{$P$ value ${ }^{\#}$} & & \multicolumn{2}{|c|}{$95 \%$ confidence } \\
\hline & $\begin{array}{c}\text { second } \\
\text { trimester } \\
\text { delivery } \\
\text { (13-26 weeks) }\end{array}$ & $\begin{array}{l}\text { third } \\
\text { trimester } \\
\text { delivery } \\
\quad \text { (after 26 } \\
\text { weeks) } \\
\end{array}$ & & & & upper \\
\hline $\begin{array}{l}\text { Total no. of } \\
\text { samples }\end{array}$ & 14 & 43 & & $\rightarrow$ & - & - \\
\hline U.parvum & $35.7 \%(5)$ & $14 \%(6)$ & 0.07 & 3.4 & 0.9 & 13.7 \\
\hline U.urealyticum & $7.1 \%(1)$ & $2.3 \%(1)$ & 0.40 & $3.2-$ & 0.2 & 55.3 \\
\hline G.vaginalis & 0 & $23.3 \%(10)$ & 0.04 & - & - & - \\
\hline GBS & $21.4 \%(3)$ & $14 \%(6)$ & 0.50 & 1.6 & 0.4 & 7.9 \\
\hline
\end{tabular}

\#Fisher's Exact test. 